

LIORARY

EOYAL ONTA?IO MIGEISM 
Digitized by the Internet Archive in 2012 with funding from Royal Ontario Museum 


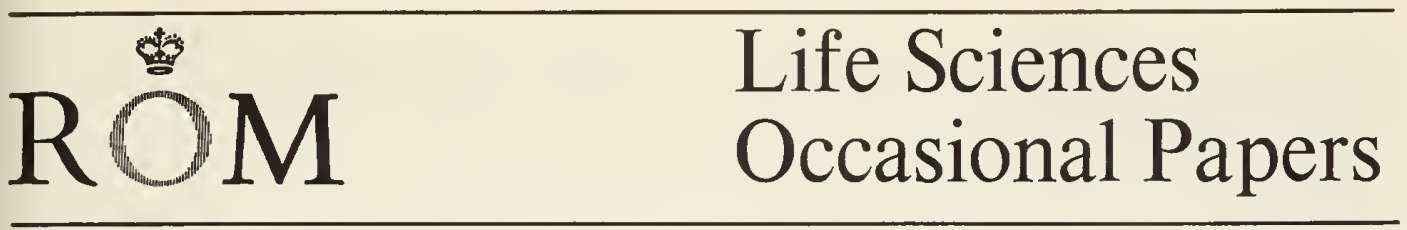

Royal Ontario Museum

July 22, 1968

No.11

\section{A New Subspecies of the Red Fig-eating Bat from Puerto Rico}

by E. Raymond Hall ${ }^{1}$ and J. R. Tamsitt ${ }^{2}$

The red fig-eating bat, Stenoderma rufum Desmarest, was made known to science by French naturalists in the second decade of the last century on the basis of a single specimen from an unknown locality. A century later Dr. H. E. Anthony (1918:354) referred fossil remains from caves in Puerto Rico to this species. In 1960, Hall and Bee (1960: 67-75) reported on three specimens captured in 1957 on St. John Island of the Virgin Islands group, described in detail the taxonomic history of this species, and emphasized that it was not extinct.

Unknown to those authors a specimen had been obtained in 1943 (July 23) on St. Thomas Island of the Virgin Islands group by Harry Beatty. It reposed in the U.S. National Museum among unidentified specimens for approximately 20 years until Dr. Charles O. Handley, Jr. identified it and installed it in its correct position in the spirit collection.

In March of 1965 Dr. Albert Schwartz collected two specimens in Puerto Rico and in the period July 1965-April 1967 J. R. Tamsitt and Dr. Darío Valdivieso collected 10 more individuals in Puerto Rico.

1. University of Kansas Museum of Natural History, Lawrence, Kansas, U.S.A.

2. Department of Mammalogy, Royal Ontario Museum.
The specimens from St. John Island, as noted by Hall and Bee (op. cit.), are indistinguishable from the holotype of Stenoderma rufum. The spirit specimen from St. Thomas Island, two miles to the west of St. John, likewise agrees in colour with the holotype. But the 12 specimens from Puerto Rico, 50 miles west of St. John, all differ appreciably from those to the east and may be known as

\section{Stenoderma rufum darioi new subspecies}

Holotype-Female, adult, skin and skull, No. 43192 Royal Ontario Museum, University of Toronto; from one mile northwest of $\mathrm{El}$ Yunque Peak, 355 meters elevation, Puerto Rico; obtained on November 21, 1965, by Darío Valdivieso and J. R. Tamsitt (field number 1845 J. R.T.).

Range—Known only from Puerto Rico.

Diagnosis-Upper parts near $(l)$ Dresden Brown (Ridgway, 1912: Pl. 15); under parts paler owing to grayish tips on hairs; pinnae of ears black distally and otherwise dark brown; pinnae sparsely haired internally and nearly naked on distal half of external surface(Fig. 1).

Comparison-From Stenoderma rufum rufum, $S$. $r$. darioi differs as follows: darker, upper parts being near $(l)$ Dresden Brown instead of 


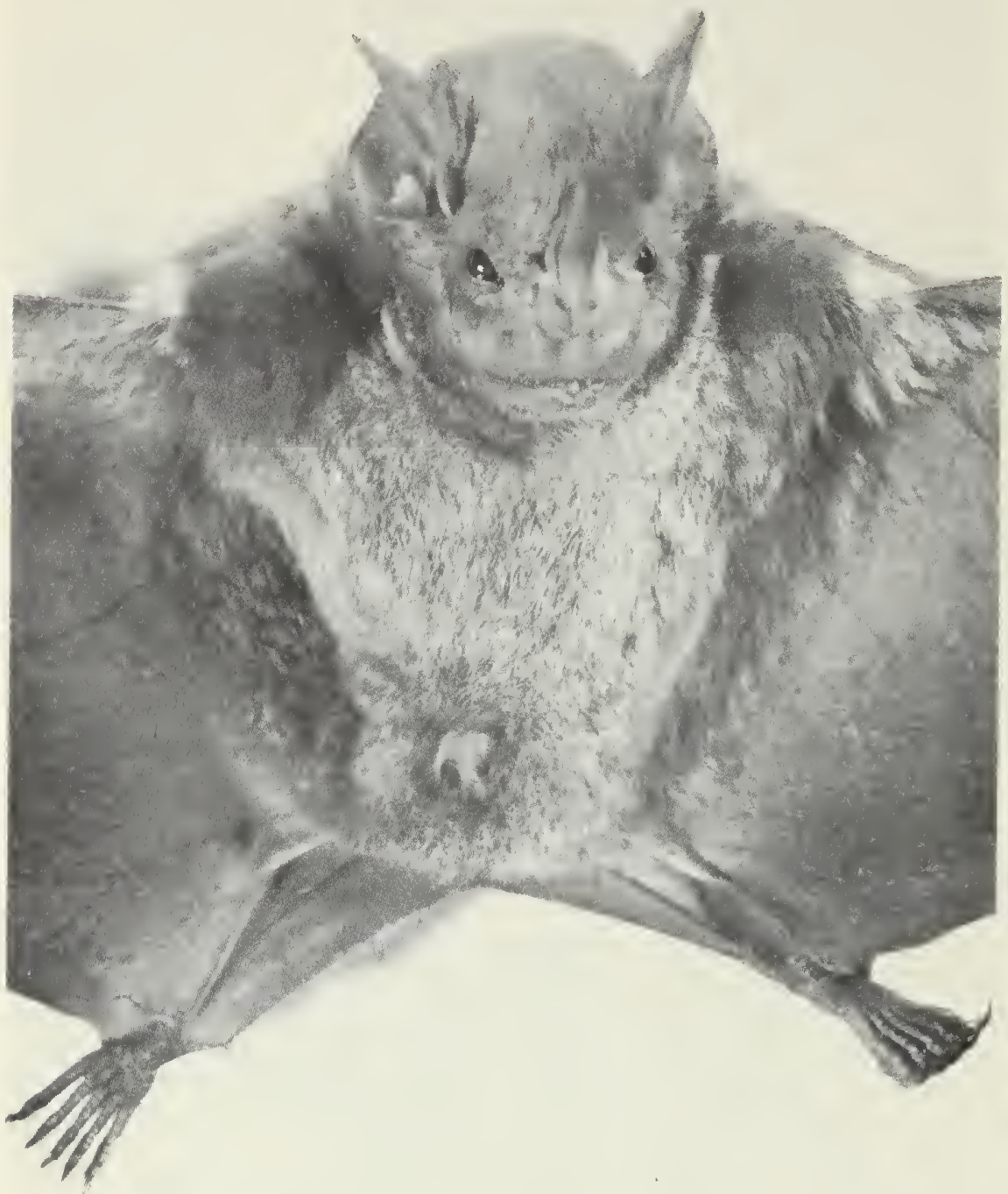

Figure 1

Stenoderma rufum darioi, subadult male, topotype, alive; No. 208982 American Museum of Natural
History, face and venter, approximately $16 / 10 \times$. Photo by José Ramírez, July 1965. 
near $(j)$ Buckthorn Brown; more contrast between colour of upper parts and under parts; pinnae of ears black to dark brown instead of pale brown.

Measurements (of adults) - An average and the extreme measurements in millimeters of three males are followed by an average and the extremes of four females: Total length (head and body) $\sigma^{7} 59$ (53-65), 965 (60-71); hind foot 11.2 (10-13.5), $12.6(12.0-13.0)$; ear from notch 18.3 (17.0-18.9), 19.2 (18.0-20.2); forearm 47.8 (47.5-48.0), 48.5(46.7-49.5); greatest length of skull including incisors 22.4 (22.322.6), 23.5 (23.2-23.9); condylobasal length 18.5 (18.3-18.6), 19.4 (19.2-19.6); length of palate from an incisive foramen to postpalatal notch 1.4(1.2-1.5), 1.8 (1.6-2.0); crown length of right maxillary tooth-row $\left(\mathrm{C}^{1}-\mathrm{M}^{3}\right) 6.7$ (6.6$6.8), 7.0(6.8-7.2)$; breadth across first upper molars 9.6 (9.4-9.7), 9.7 (9.5-9.9); zygomatic breadth 15.1 (15.0-15.3), 15.2(14.7-15.5); mastoidal breadth 12.4 (12.3-12.5), 12.8 (12.5$13.2)$; least postorbital breadth 5.6 (5.5-5.8), 5.7 (5.5-6.0). Corresponding measurements of the holotype of $P$. $r$. darioi are $60,12.3,18.7$, $46.7, \longrightarrow, 19.2,1.7,6.1,7.5,14.7,12.5,5.5$.

Remarks-A detailed description of the species has been published in the journal Mammalia (Hall and Bee, 1960: 72), and the diagnosis of the subspecies darioi lists only those features in which it differs from the nominate subspecies, Stenoderma rufum rufum.

The geographic range of the species probably is more extensive than now known. The locality of capture of the holotype of Stenoderma rufum is unknown and the name is associated with, and applied to, specimens from St. John Island (see Hall and Bee, op. cit.) and to No. 271210 USNM from St. Thomas Island because they are indistinguishable from the holotype in pallor of pelage and ears.

Shape of skull, size of skull (Fig. 2), and size of the entire individual is not known to differ between the two subspecies but colour of pelage does differ, and consistently. Moreover, the habitats of the two subspecies differ. $S$. $r$. rufum has been found in dry arborescent vegetation at St. John Island (total 1966 precipitation at Cruz Bay, 46. 77"'; U.S. Dept. Commerce, 1967), whereas S.r. darioi has been found typically in dense rain forest in Puerto Rico (total 1966 precipitation at El Verde, 116.12" ; ibid.: 152). A case could be made for according specific instead of subspecific rank to the two kinds because their geographic ranges do not meet and because intergradation is unlikely. Even so, subspecific rank for the two kinds seems preferable because it is assumed that intergradation would occur if a land connection were established between Puerto Rico and Saint Thomas Island since the degree of difference between the two kinds is no greater than between certain pairs of subspecies of bats on the mainland of North America that do intergrade with each other.

Parturition in Stenoderma rufum has been described by Tamsitt and Valdivieso (1966: 352 ). In commenting on the specimens of $S$. rufum from St. John Island and in comparing them with the fossil remains of Stenoderma from caves in Puerto Rico, Hall and Bee (1960:73) stated that the fossils were larger and more massive and therefore chose not to identify them, at that time, to subspecies. With even better reason, no attempt to do that is made in the present paper because Messrs. J. R. Choate and E. C. Birney have a study of those fossils well advanced and assure us that the results of their study, when published, will show that the fossils are not referable to the taxon Stenoderma rufum darioi.

Specimens examined-Total of 12, all from Puerto Rico: type locality 10 (Royal Ontario Mus., 5; Amer. Mus. Nat. Hist., 3; Univ. Kansas Mus. Nat. Hist., 2). Seventeen and one-half kilometers northeast of Utuado, 2 (collection of Dr. Albert Schwartz).

Acknowledgments-Field work that yielded most of the specimens here reported on was made possible by means of Graduate Research Training Grant 5 T1 A1 15 from the National Institutes of Health, U.S. Public Health Service and by some other financial support from the Explorers' Club. Also, financial assistance that yielded some of the necessary comparative materials was provided from the Watkins Fund through the Kansas University Endowment Association. We are indebted to Dr. Howard T. Odum for permission to set bat nets at the Puerto Rico Nuclear Centre Research Station, and thank L. R. Warren and José R. Ramírez for providing the photographs reproduced here as figures 1 and 2. Also we are grateful to Drs. Albert Schwartz and Charles O. Handley, Jr. 

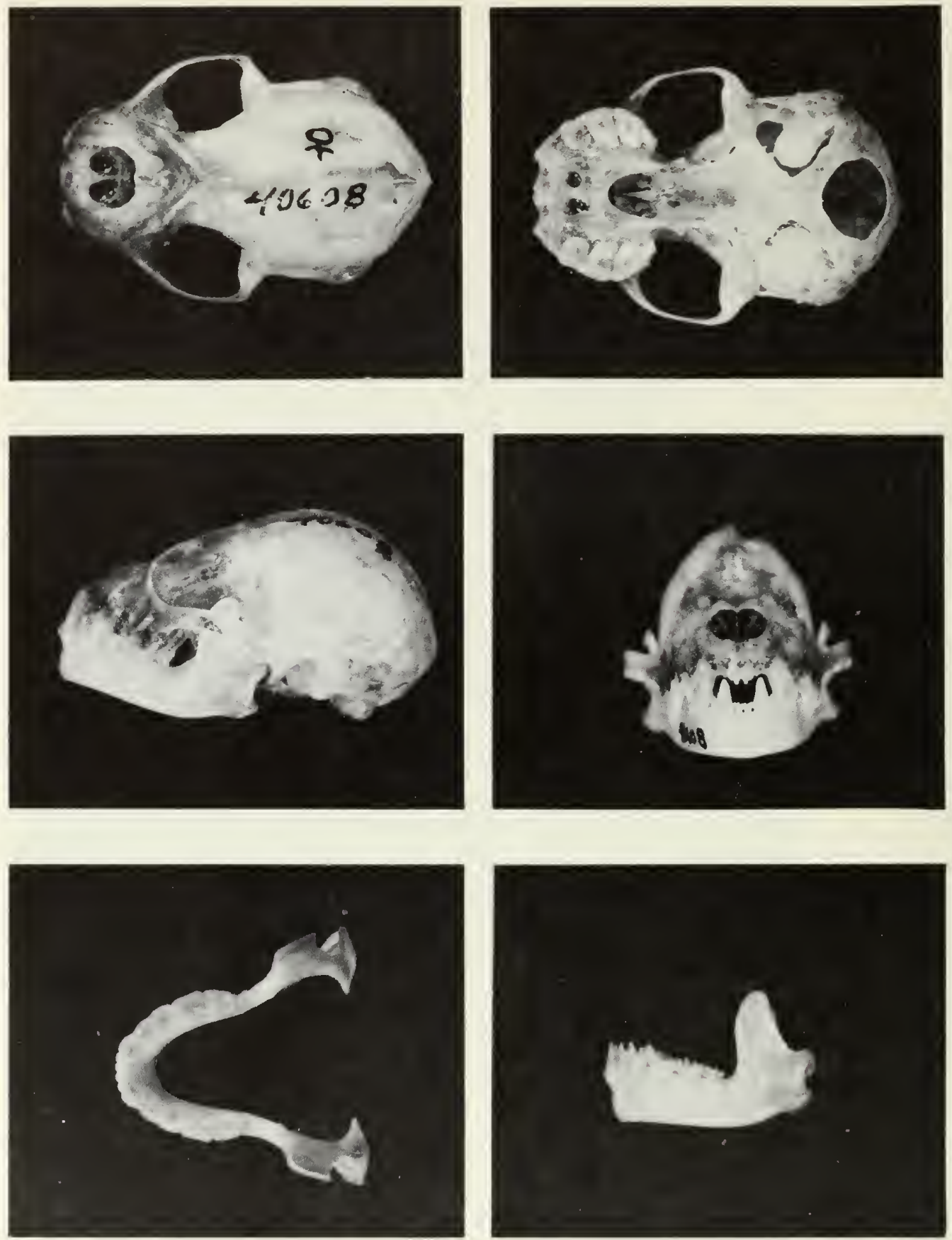

Figure 2

Stenoderma rufum darioi, adult female, topotype; No. 40608 Royal Ontario Museum, cranium and mandible,

approximately $14 / 10 \times$. Photos by L. R. Warren, January 1968. 
for lending certain specimens.

The subspecific name darioi is proposed to honor Dr. Darío Valdivieso for his contributions to neotropical zoology.
Summary-A phyllostomid bat from Puerto Rico, West Indies, is described and named as a new subspecies of the species Stenoderma rufum.

\section{Literature Cited}

Anthony, H. E., 1918

The indigenous land mammals of Porto Rico, living and extinct. Mem. Amer. Mus. Nat. Hist., n.s., 2: 331-435, pls. 55-74, 55 figs., June

Hall, E. R. and J. W. Bee, 1960

The red fig-eating bat Sternoderma rufum Desmarest found alive in the West Indies. Mammalia, 24, 1:65-75, May 27

Ridgway, R., 1912

Color standards and color nomenclature. Washington, D.C., iv, 44 pp., pls. 1-53

Tamsitt, J. R., and D. Valdivieso, 1966

Parturition in the red fig-eating bat, Sternoderma rufum. Jour. Mamm., 47: 352-353, May 26

U.S. Department of Commerce, 1967

Annual Summary, 1966. Puerto Rico and Virgin Islands. Climatological Data, 12: $151-156$ 


LIERTARY

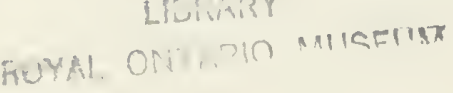



